\title{
Optic nerve grey crescent: an assessment using swept-source OCT
}

\author{
Amar Pujari, Rohan Chawla, Shreyas Temkar, Mohamed Ibrahime Asif
}

Department of Ophthalmology, Dr. Rajendra Prasad Centre for Ophthalmic Sciences, AllMS, New Delhi, India

\section{Correspondence to Dr Amar Pujari, dramarpujari@gmail.com}

Accepted 7 January 2018

\section{DESCRIPTION}

Optic nerve head is an area of opening within the scleral canal; pigmentary changes at the margins and around the disc encompass a few important differential diagnoses. Optic nerve head grey crescent is one such clinical entity where it is characterised by bilateral greyish pigmentation of the temporal neuroretinal rims. The appearance is due to an internal extension of Bruch's layer into the peripapillary scleral canal. It was first noted by Shields in 1980 in African-American patients. The pigmentation mainly lies within the optic nerve head; in contrast, the alpha and beta zone lies outside the optic nerve head. The beta zone of peripapillary region is mainly an atrophy of the choroid and retinal layers for a varying degree with underlying visible sclera, whereas the crescent area is an area of encroachment of the peripapillary layers onto the disc. The clinical implication of this clinical entity is that this area of pigmentation masks the underlying healthy neuroretinal rim leading to misinterpretation and overestimation of the size of the optic disc cupping and false-positive diagnosis of glaucoma. ${ }^{12}$
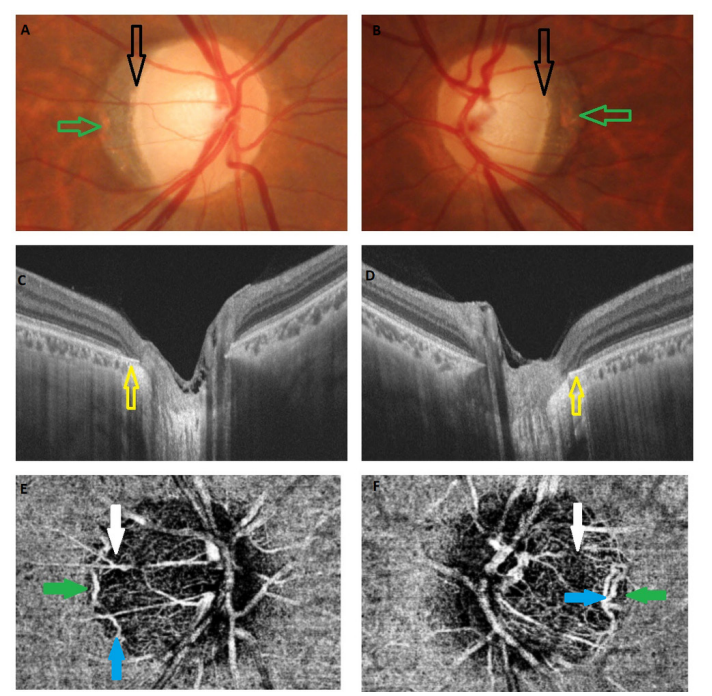

Figure 1 ( $A$ and $B$ ) Both eyes with normal-sized optic disc showing greyish pigmentation of the temporal margin (between green and black arrows). (C and D) SSOCT showing thickened RPE-Bruch's complex at the level of the scleral canal. (E and F) OCTA at the level of choriocapillaris delineated the actual margin (green arrows), which is well beyond the falsely concluded margins (white arrows). Branches of arterial ring of ZinnHaller can be appreciated (blue arrow). SSOCT, sweptsource optical coherence tomography.

\section{Learning points}

- Better anatomical understanding of the optic nerve head and its relation with the surrounding peripapillary retina is possible using sweptsource optical coherence tomography.

- The actual margin of the optic disc lies beyond the clinically appreciable margins, which was appreciated quite accurately.

Here we discuss one such case using sweptsource optical coherence tomography (OCT) to delineate the actual anatomical margins of the optic nerve head who was diagnosed with glaucoma. In a 40-year-old male patient having a visual acuity of 20/20 in each eye with unremarkable anterior segment showed normal-sized optic disc (green arrows) with crescentic greyish appearance of the temporal neuroretinal rim leading to overestimation of the optic disc cupping (figure 1A,B black arrows). Intraocular pressures were normal; swept-source OCT revealed the edge of the hyper-reflective RPEBruch's membrane complex corresponding to the crescent-shaped temporal disc margin (figure 1C,D, yellow arrows). Subsequently, Optical coherence tomography angiography (OCTA) at the level of superficial choroidal layer delineated the actual margins of the optic disc with overlying continuity of the retinal vessels (figure 1E,F, yellow arrows), whereas the falsely concluded margin of the optic disc canal lies significantly within the actual margins (white arrows). The patient was reassured and kept under follow-up. Arterial ring of ZinnHaller can also be appreciated (blue arrow). ${ }^{3}$

Contributors All authors have evaluated the case in detail. After critically analysing the educational value of the case, all authors wrote the report together.

Funding This research received no specific grant from any funding agency in the public, commercial or not-for-profit sectors.

Competing interests None declared.

Patient consent Obtained.

Provenance and peer review Not commissioned; externally peer reviewed.

(c) BMJ Publishing Group Ltd (unless otherwise stated in the text of the article) 2018. All rights reserved. No commercial use is permitted unless otherwise expressly granted.

\section{REFERENCES}

1 Arora S, Rayat J, Damji KF. Optic nerve gray crescent can confound neuroretinal rim interpretation: review of the literature. Can J Ophthalmol 2014;49:238-42. 


\section{Images in...}

2 Roddy GW, Brodsky MC, Chen JJ. Optic Nerve Gray Crescent. Ophthalmology 2017;124:1022.

3 Ishida T, Jonas JB, Ishii M, et al. Peripapillary arterial ring of zinn-haller in highly myopic eyes as detected by optical coherence tomography angiography. Retina 2017;37:299-304.

Copyright 2017 BMJ Publishing Group. All rights reserved. For permission to reuse any of this content visit http://group.bmj.com/group/rights-licensing/permissions.

BMJ Case Report Fellows may re-use this article for personal use and teaching without any further permission.

Become a Fellow of BMJ Case Reports today and you can:

- Submit as many cases as you like

- Enjoy fast sympathetic peer review and rapid publication of accepted articles

- Access all the published articles

- Re-use any of the published material for personal use and teaching without further permission

For information on Institutional Fellowships contact consortiasales@bmjgroup.com

Visit casereports.bmj.com for more articles like this and to become a Fellow 